\title{
大出カハイブリッドプラズマ溶射法の開発
}

\author{
浜谷秀樹 小原昌弘藤 雅雄 \\ 新日本製鉄柣式会社接合研究センター
}

J. Japan Inst. Metals, Vol. 63, No. 1 (1999), pp. 135-143

Special Issue on Recent Development of Thermal Plasma Materials Processing

\section{Development of High Power Hybrid Plasma Spraying}

\author{
Hideki Hamatani, Masahiro Ohara and Masao Fuji
}

Welding \& Joining Laboratory, Nippon Steel Corporation, Futtsu 293

\begin{abstract}
This study is aimed at developing a high power hybrid plasma spraying device with a maximum radio frequency input power of $300 \mathrm{~kW}$, in order to improve the strength and adhesion strength of sprayed coating. The stability of plasma, energy efficiency, and melting state of particles were investigated under several conditions, and then characterization of coating was carried out. The stability of plasma condition is strongly influenced by gas flow rate of $\mathrm{Ar}, \mathrm{N}_{2}$, and $\mathrm{H}_{2}$ mixture against the power supplied. The energy efficiency of equipment is approximately $14 \%$. The energy is lost mainly by joule's heat in the oscillator circuit. Using this device, the maximum particle diameter for full melting is approximately $250 \mu \mathrm{m}$. In the plasmas praying by not fully melted particles, the strength of coating decreases with increasing particle diameter because of increased porosity size. On the other hand, in the spraying by fully melted particles, it is found that the high strength of coating and the high adhesion strength at the interface between substrate and coating is obtained at large diameter particles. This tendency is explained by easy remelting or sintering at the interface between large particles. Actually, our experiment demonstrates that the maximum strength of coating and adhesion strength is more than 1300 and $250 \mathrm{MPa}$ respectively, by using fully melted particles with maximum diameter.
\end{abstract}

(Received July 21, 1998; In Final Form September 14, 1998)

Keywords: plasma spraying, hybrid plasma, radio-frequency plasma, supper alloy, strength of coating, adhesion strength of coating

\section{I．緒言}

現在の工業界における目ざましい発展の背景では，部材あ るい性設備が熱的にも機械的にも益々荷酷な環境で使用され るようになってきている。この環境下での耐久性を高めるた めの技術として，素材表面へのコーティングは大いに期待さ れている技術である。様々なコーティング技術の中で溶射法 は大面積への厚い被膜形成が可能な手法で，最も経済性の高 いプロセスの一つといえる.

この溶射法は加熱源（溶射材料の）によってフレーム溶射と プラズマ溶射に大別できる、フレーム溶射に利けるプロセス 開発は，フレームの高速化の傾向にあり, HVOF(High Velocity Oxygen Fuel), HVAF(High Velocity Air Fuel)な ぞが開発されている(1).これらでは溶射粒子の高速化によ り，溶射材料の運動エネルギー，並びに衝突時の熱エネルギ 一を利用して被膜特性の向上を図っている。一方，プラズマ 溶射におけるプロセス開発は，プラズマ中のエネルギー密度 を上げたり，高温領域を拡大して，溶射粒子の“完全溶融” 犋万力向にある。例えば水プラズマ溶射 ${ }^{(2)}$ ，減压プラズマ
溶射 $^{(3)}$, 高出力プラズマ溶射 (最高 $250 \mathrm{~kW}$ ), 高圧下での溶

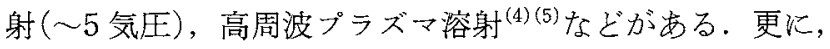
複合熱源として，高周波プラズマと直流プラズマを重畳させ たハイブリッドプラズマ溶射法 ${ }^{(6)-(8)}$ も開発されている。こ の手法は，高周波プラズマの欠点であるプラズマの不安定性 やプラズマジェットの低指向性と直流プラズマの久点である プラズマ内部の大きい温度，速度勾配を克服することを狙っ ている.

ハイブリッドプラズマ溶射法に沏ける直流プラズマの役割 は，高周波プラズマの種火と溶射粒子の加速機である。一 方，高周波プラズマは溶射粒子の加熱機の役割をしている. そして粒子速度が従来の直流プラズマ溶射法の1/5程度と低 いために粒子の完全溶融や大きい粒子の溶射が可能といわれ ている(7)。実際，高周波出力 $50 \mathrm{~kW}$ 級の装置を用いた場合 の Ti 溶射では最大粒径 $120 \mu \mathrm{m} の$ 材料が ${ }^{(8)}$ ， た, $\mathrm{Y}_{2} \mathrm{O}_{3}$ 安 定化 $\mathrm{ZrO}_{2}$ 溶射では最大 $80 \mu \mathrm{m}$ の粒子の溶射が報告されてい る(7).ここでは大さい粒子を用いると，基板に到達したとき の粒子の保有する熱容量が大きくなり，粒子の凝固過程での 界面反応や熱桩散が促進されるために界面強度が向上すると されている，したがって，更に大きい径の溶射を可能とする 
なれば更に被膜の特性が向上する可能性がある(4)，そのため には，プラズマの大出力化が一つの手段である.

また，低出力のハイブッッドプラズマ溶射法では, 高周波

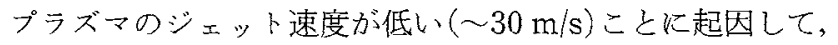
一旦溶融した溶射粒子が基板到達前に冷却してしまう。した がって，溶射距離(基板とプラズマトーチ間の距離)を短くし なくてはならない，そのため，複雑な形状の基板への溶射 や，基板への熱影響が無視できないという尔点がある。この 課題を解決するためには，プラズマ入力の増加によりプラズ マ体積を膨張させることが有効と考克られる。

以上を背景として，本研究では，被膜特性のさらなる向上 と, 先の課題(溶射距離 $100 \mathrm{~mm}$ 以上での溶射を可能)を解 決するため, $300 \mathrm{~kW}$ のハイブリッドブラズマ溶射装置の開 発を行った。本論文は開発過程に蚹引る問題について検討し た結果を報告する。まず，プラズマ装置として安定させるた めの条件を探索した。攵してプラズマの安定性を確保したう 兄で，エネルギー効率(電気的出力以対するプラズマ化エネ ルギー)や，溶射可能な最大の粒子径について検討した，後 者に関しては，高周波出力と溶融可能な粒子径の関係と，粒 子径と被膜の強度特性との相関関係を明確にすることに主眼 を扣いて実験を行った。

\section{II、実 験 方 法}

Fig. 1 ほイブリッドプラズマ溶射装置の概略図を示す. 本装置は高周波プラズマを発生させるための高周波電源部 (高圧トランス, 整流回路, 発振回路), 直流プラズマを発生 させるための直流電源部，プラズマトーチ部，ガス供給部， 粉末供給装置，氷冷系，防栕・遮光用壁ならびに基板の駆動 系からなっている.高周波発振回路の中で, 高周波電源とプ ラズマトーチを接続するプレートの長さは $1 \mathrm{~m}$ である(大型 構造物への溶射を行らため)，

Fig. 2 にハイブリッドブラズマトーチの概略図を示す. トーチは高周波プラズマを発生させるための高周波コイル， プラズマガス流を制御するための水冷 2 重管，直流プラズ マガン,プラズマ作動ガスの供給系ななびに粉末の供給系 から構成されている，直流プラズマは通常のプラズマ溶射法 に用いられているもので，陰極-陽極間で放電させてプラズ

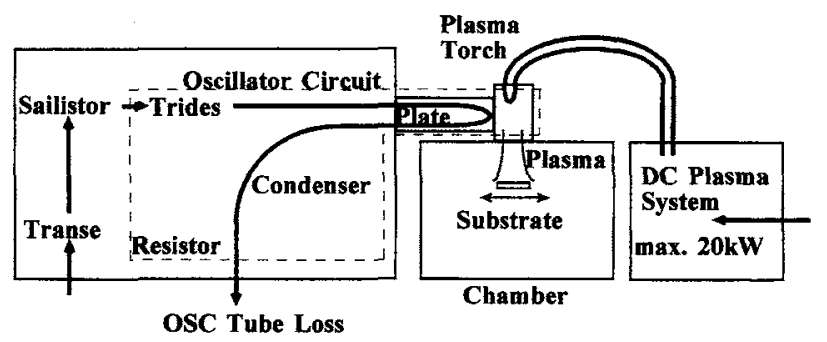

Fig. 1 Schematic diagram of the hybrid plasma spraying system.
マジェットを形成している。一方，高周波プラズマはコイル を流れる高周波電流が作る高周波磁場によりプラズマ作動ガ スに入熱を与え，そのジュール発熱でできる誘導結合型のプ ラズマである。このプラズマガスはトーチ軸に対して平行方 向之回転方向に供給する。この図で示す Gap は水冷 2 重内 壁と直流プラズマガンの外壁との隙間で，この隙間から高周 波プラズマ用のガスを供給する。ハイブリッドプラズマの点 火は，あらかじめ点火さ好た直流プラズマを種火として，高 周波プラズマ用のプラズマ作動ガスを供給し，高周波出力を 徐々にあげて高周波プラズマを点火する順序で行った。

この装置を用いてまず，(1)プラズマを点灯させるための Gap 幅とプラズマ作動ガス流量の関係，(2)高周波出力と安 定したハイブリッドプラズマを形成させるためのガス(Ar$\mathrm{N}_{2}-\mathrm{H}_{2}$ ) 流量の関係を明らかにした。実験条件をTable 1 K 示す。ここでプラズマが安定するとは，プラズマが不安定に なり消隇しないこと，霖よび高周波ト一チがプラズマからの 熱により破損しないことと定義した。また，高周波プラズマ の電压，電流值柱プレト部での值を用いている.

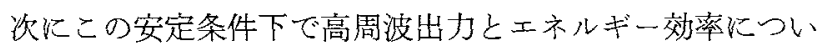
て検討した. Fig. 1 の発振回路では真空管, コンデンサー, 抵抗部，ならびにこれらを接続する銅平板での高周波電流の ジュール損(Oscillator)，プラズマトーチ部ではプラズマか らト一チへの放射熱損，李た高周波ュイル中では誘導加熱損 などがある(Fig. 1, Fig.2 中の太線の矢印)，そのため実際 Kプラズマに投与されるエネルギーはプレートでの出力から これらの損失分を除去する必要がある。これらのエネルギー 損失怜㑢水の水量と温度上昇から算出した。 そしてェネル

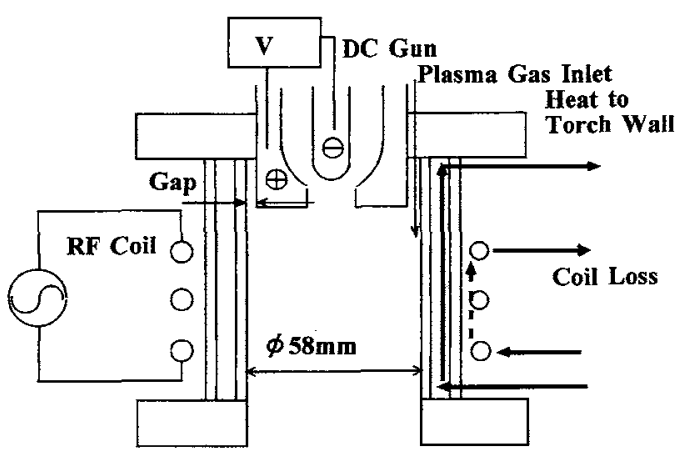

Fig. 2 Schematic diagram of the hybrid plasma torch.

Table 1 Experimental plasma condition.

\begin{tabular}{lcr}
\hline \hline Input Power; & & \\
RF(Radio Frequency): & $50-270$ & $(\mathrm{~kW})$ \\
DC(Direct Current): & $100-400$ & $(\mathrm{~A})$ \\
Gas Flow Razte; & & \\
Tangential Ar Gas: & $40-80$ & $\left(\mathrm{~L} \cdot \mathrm{min}^{-1}\right)$ \\
Radius Ar Gas: & $40-80$ & $\left(\mathrm{~L} \cdot \mathrm{min}^{-1}\right)$ \\
Tangentail N $\mathrm{N}_{2}$ Gas: & $5-100$ & $\left(\mathrm{~L} \cdot \mathrm{min}^{-1}\right)$ \\
Tangential $\mathrm{H}_{2}$ Gas: & $0-40$ & $\left(\mathrm{~L} \cdot \mathrm{min}^{-1}\right)$ \\
DC Plasma Ar Gas: & 10 & $\left(\mathrm{~L} \cdot \mathrm{min}^{-1}\right)$ \\
\hline
\end{tabular}


ギー効率を実際にプラズマに投与される熱量と電気的な高周 波出力との比で定義した。な拝，この熱量は電気的な出力か ら装置各部位の冷却水の水温と流量から算出される熱量の差 から算出した。

そして高周波出力に対する最大に溶融できる粒子径を明確 にするための実験を行った．分級した粒子を，所定の高周波 出力のプラズマに供給し，溶融粒子を急冷（溶射距離 400 $\mathrm{mm}$ K設置した水槽内) し，粒子の組織变化と被膜形成の可 否から粒子の溶融/未溶融を判断した。また，チャンバー内 壁への蒸発成分の付着物形成炕より粒子からの蒸発有無を求 めた。詳細な実験条件を Table 2 に示方。溶射に用いた材 料虫 Co 基合金(ステライトNo. 6，山陽特殊鋼製，粒径：10 〜 500 $\mu \mathrm{m}$ )である.

秀た，高周波出力の粒子の変形度への効果を検討するた め，溶射距離 $200 \mathrm{~mm}$ に基板を設置し，この基板上飞粒子 を 1 層の又溶射して(基板の予備加熱は無し)，粒子の变形 度を測定した。変形度は変形粒子の平均径と原料粒子の平均 径の比で定義した。

以上の実験を行った後，未溶融粒子が被膜に混在する場合 としない場合について，被膜特性への粒子径の効果を検討し た。被膜は予備加熱をしないSUS304 基板の上に粒径と出 力を変えて形成した。得られた被膜を Fig. 3 に示与被膜強 度試験抽よび密着強度試験により評価した。強度試験では， 基板上に形成した唇み $1 \mathrm{~mm}$ 被膜から被膜単体で

Table 2 Experimental spraying condition.

\begin{tabular}{lc}
\hline \hline Gas Flow Rate; & \\
Powder Feed Ar Gas: & $0.5\left(\mathrm{~L} \cdot \mathrm{min}^{-1}\right)$ \\
Powder; & \\
Material: & Stellite No. 6 \\
Feed Rate: & $12-48\left(\mathrm{~g} \cdot \mathrm{min}^{-1}\right)$ \\
Diameter: & $10-500(\mu \mathrm{m})$ \\
Substrate; & $\mathrm{SUS304}$ \\
Material: & $150(\mathrm{~mm})$ \\
Position: & \\
(Distance between the exit of & \\
plasma torch and substrate) & \\
\hline
\end{tabular}

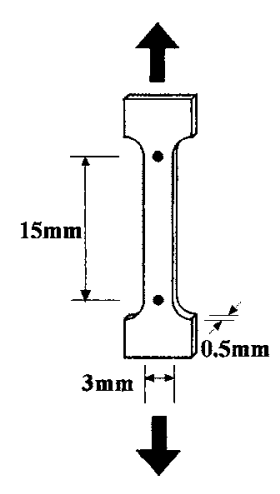

(a)

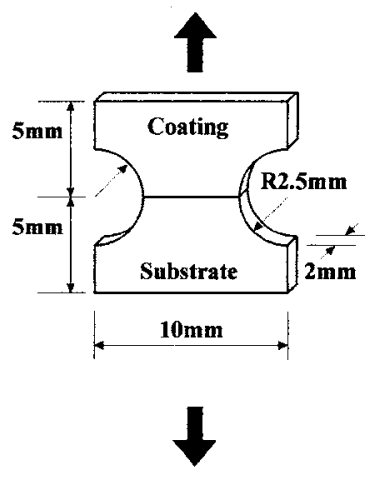

(b)
Fig. 3 Schematic diagram of the evaluations of coatings.
JIS $13 \mathrm{~B}$ 試験片の約 $1 / 5$ のに機械加工した試験片（標点間距離 $15 \mathrm{~mm}$, 平行部幅 $3 \mathrm{~mm}$, 厚さ $0.5 \mathrm{~mm}$ )を用い, 引張試験に より強度を測定した。また，密着強度試験用に，厚みが約 6 $\mathrm{mm}$ の溶射をした後，機械加工をし，試験片を作製した。 して溶射被膜と基板の界面に垂直方向に引張試験を行って密 着強度を評価した。な叔この試験片に和ける界面両端の応 力集中は，鋼鉙単体で拈よそ1.5倍になる。をた，得られた 被膜並びに溶射粉末の組織のエッチングにはショウ酸電解エ ッチングを用いた。

\section{III、実験結果および考察}

\section{1. プラズマの安定}

ハイブリッドプラズマの点火は，先述したように直流プラ ズマを点火し，かつ高周波プラズマの作動がスを供給しつ つ，徐々に高周波出力を上げていった。このとき作動ガスに はプラズマ化しやすい Arのみを用いた。この点火に必要な Ar 流量はトーチの Gapによって変化した. Gap と点火に必 要な $\mathrm{Ar}$ ガス流量(回転力向と半径方向の流量は等しく設定) の関係をFig. 4 に示す。この Gap が大さくなるとプラズマ 着火に必要ながス流量が多くなることがわかる。すなわち， プラズマはめる程度ガス流速が高い汪らが着火しやすいとい らことになる。これは流速が高い漂らが，ガス分子同士，分 子/電離気体の衝突が多くなり，エネルギ一伝達がしや寸く なったためと思わ机る，以降，後述する結果ではこの Gap $2.0 \mathrm{~mm}, \operatorname{Ar}$ 流量 $80 \mathrm{~L} / \mathrm{min}$ (回転方向, 半径方向各 $40 \mathrm{~L}$ / min)での結果である。

ハイブリッドプラズマの出力を上げる場合, 直流プラズマ のようにガス流量を一定にしてから出力を上げるのではな く, 出力の増加とともに徐々に点火時に用いた $\mathrm{Ar}$ ガスに $\mathrm{N}_{2}$ ガスの流量を増加させる必要があった．Fig. 5 に高周波 出力とその出力時にプラズマを安定させるために必要な $\mathrm{N}_{2}$

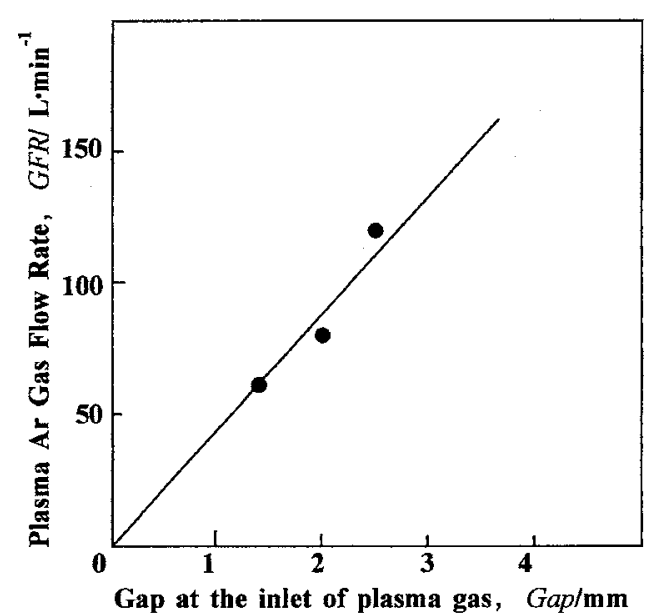

Fig. 4 The effect of gap at the inlet of RF plasma gas on the plasma Ar gas flow rate need for putting on plasma. 


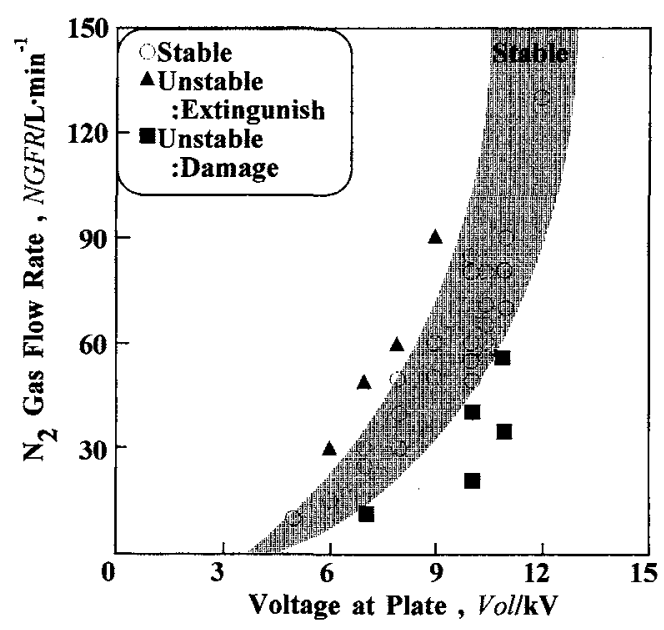

Fig. 5 The stable conditions of hybrid plasma.

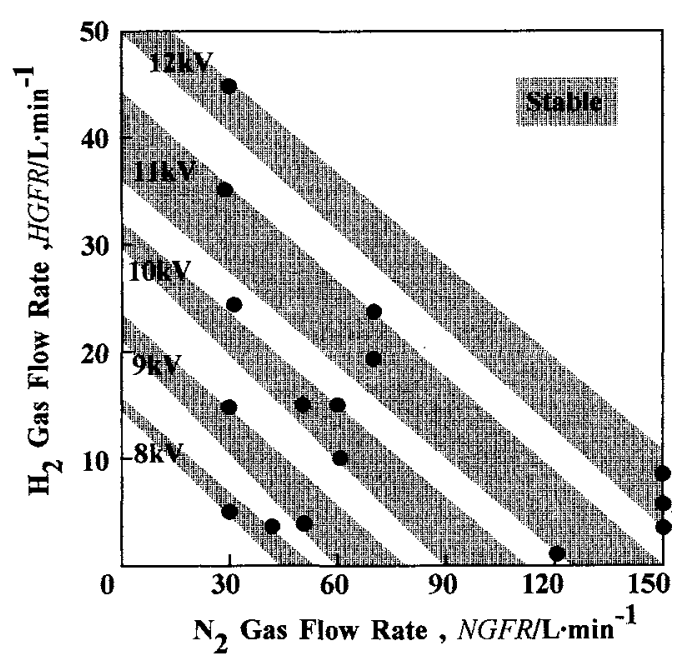

Fig. 6 Relationship between $\mathrm{N}_{2}$ and $\mathrm{H}_{2}$ gas flow rate for stable condition of hybrid plasma.

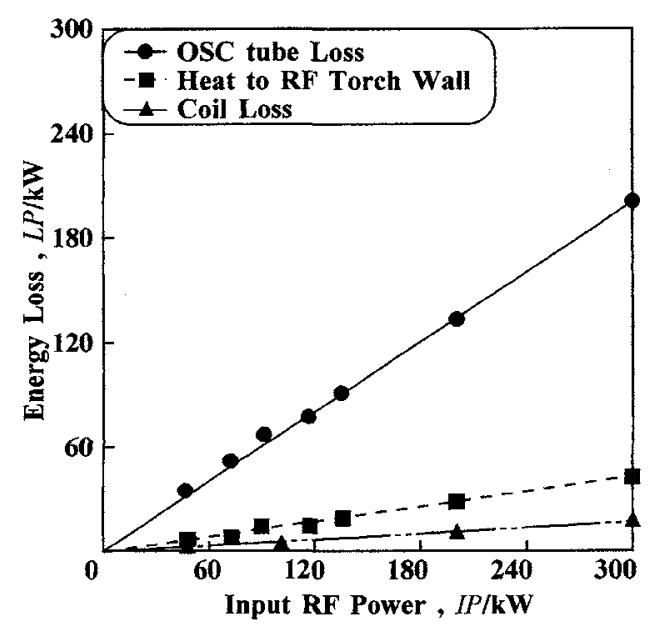

Fig. 7 The effect of input RF power on the energy loss.

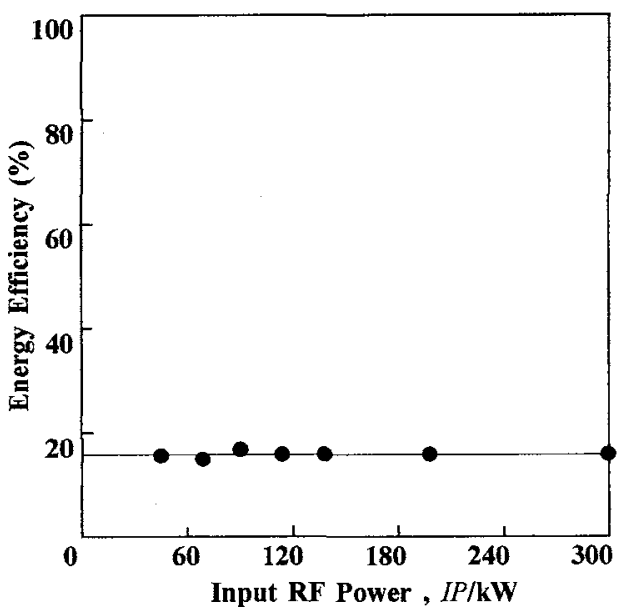

Fig. 8 The energy efficiency of hybrid plasma.

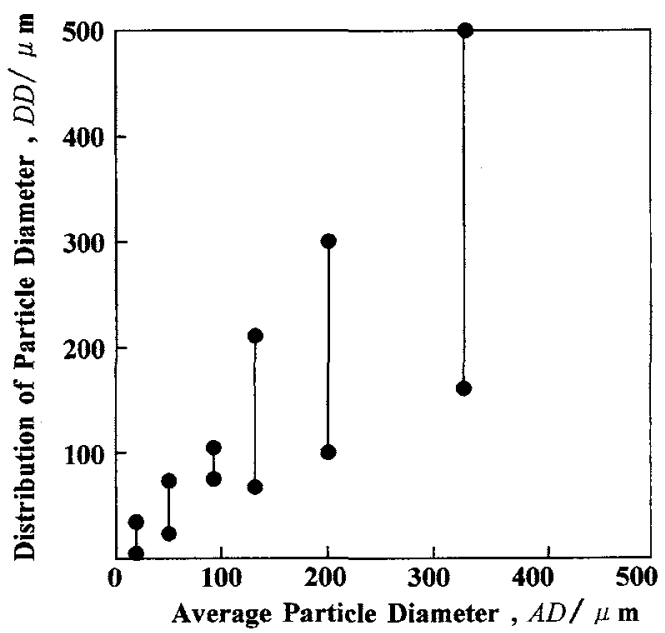

Fig. 9 Relationship between average particle diameter and the distribution of particle diameter.

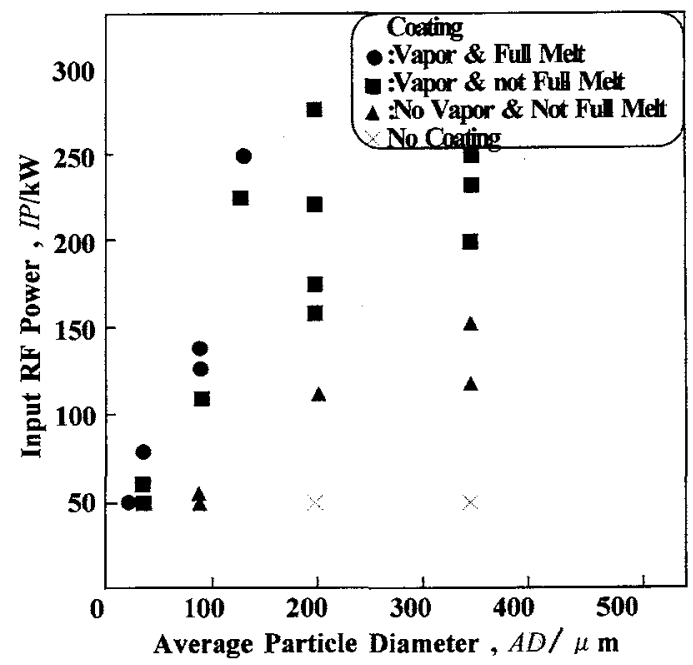

Fig. 10 The effect of particle diameter and input RF power on the melting and vaporizing of particles. 
流量の関係を示す $\left(\mathrm{N}_{2}\right.$ ガスは回転方向から供給).プラズマ 点火時には $\mathrm{N}_{2}$ は不要であるが，出力が $5 \mathrm{kV}$ (電流值 $10 \mathrm{~A}$ ) を超えると $\mathrm{N}_{2}$ が不可欠になる。ガス流量が少ない場合はプ ラズマが熱膨張し，トーチ内壁への熱影響が大きくなり，ト ーチが破損した。出力の増加に伴い $\mathrm{N}_{2}$ 流量が多くなる。 そ の後出力に対して $\mathrm{N}_{2}$ ガス流量が多い場合はプラズマが消隇 した。これはプラズマガスへ供給されるエネルギーの密度が 低下し，プラズマを維持できないためである。

出力が $11 \mathrm{kV}$ を超えると， $\mathrm{N}_{2}$ を增やしてもプラズマの膨 張は抑制しにくくなる傾向があった。これを抑制するため， $\mathrm{N}_{2}$ よりもエンタルピーが大さい水素が有効であると考光ら れるので(約 $6000 \mathrm{~K}$ 以下では $\mathrm{H}_{2}$ のほらが $\mathrm{N}_{2}$ よりもがスに 保有できるェネルギーが大きいため) ${ }^{(9)}, \mathrm{Ar}-\mathrm{N}_{2}$ 混合がスに $\mathrm{H}_{2}$ を加え，プラズマの安定化を図った。結果をFig. 6 に示 す。ここでは例壳ば電压が $11 \mathrm{kV}$ 一定のとき，プラズマを 安定させるためのガス流量は $\mathrm{N}_{2}: \mathrm{H}_{2}=120: 1 \sim 30: 35$ (L/ min)であることを示している.

$\mathrm{H}_{2}$ を添加するとプラズマを安定させるために必要な総が ス流量が少なくなっていることがわかる。このよらに $\mathrm{H}_{2}$ で プラズマ膨張を抑制できたことからプラズマの温度は高々 $6000 \mathrm{~K}$ 程度といえる。また， $\mathrm{H}_{2}$ を㬄加すると総がス流量が 少なくなり，溶射時に溶射粒子のプラズマ内部での滞留時間
が長くなり，更に，ガスから溶射粒子への熱伝達率も向上す る(ガス種依存)と考觉られることから， $\mathrm{H}_{2}$ をできるだけ多 く添加するのが適当と考它られた。

\section{2. エネルギ一効率}

以上までの結果より，プラズマ作動ガス流量や種類で 12 $\mathrm{kV}($ 約 $300 \mathrm{~kW})$ 程度まで電気的には大出力化できることが わかったが，実際にプラズマ化したエネルギーが増大してい るか梳不明である。そこで, 各高周波出力で, 装置各部位で のエネルギーロスを計測し，プラズマ化しているェネルギー 和よびエネルギー効率を検討した．Fig. 7 に各部位のエネ ルギーロス計測結果を示す．口ス分としてはOSCでのジュ 一ル損が最も大きく(損失の約 $2 / 3)$ ，次いで，トーチへの熱 放射口ス，高周波コイルでのジュール損となっていた。 た，これらのロスは電気的な出力とともに $300 \mathrm{~kW}$ までは 線形的に増大していた。これらの結果からプラズマ化へのエ ネルギー効率を算出した結果を Fig. 8 亿示す。エネルギー 効率も出力によらず14\%一定であり, 電気的に高出力化す ることにより，プラズマのエネルギーる増大していると結論 づけられる。この低いェネルギー効率の主因はプレート長さ が $1 \mathrm{~m}$ であることと考えている。
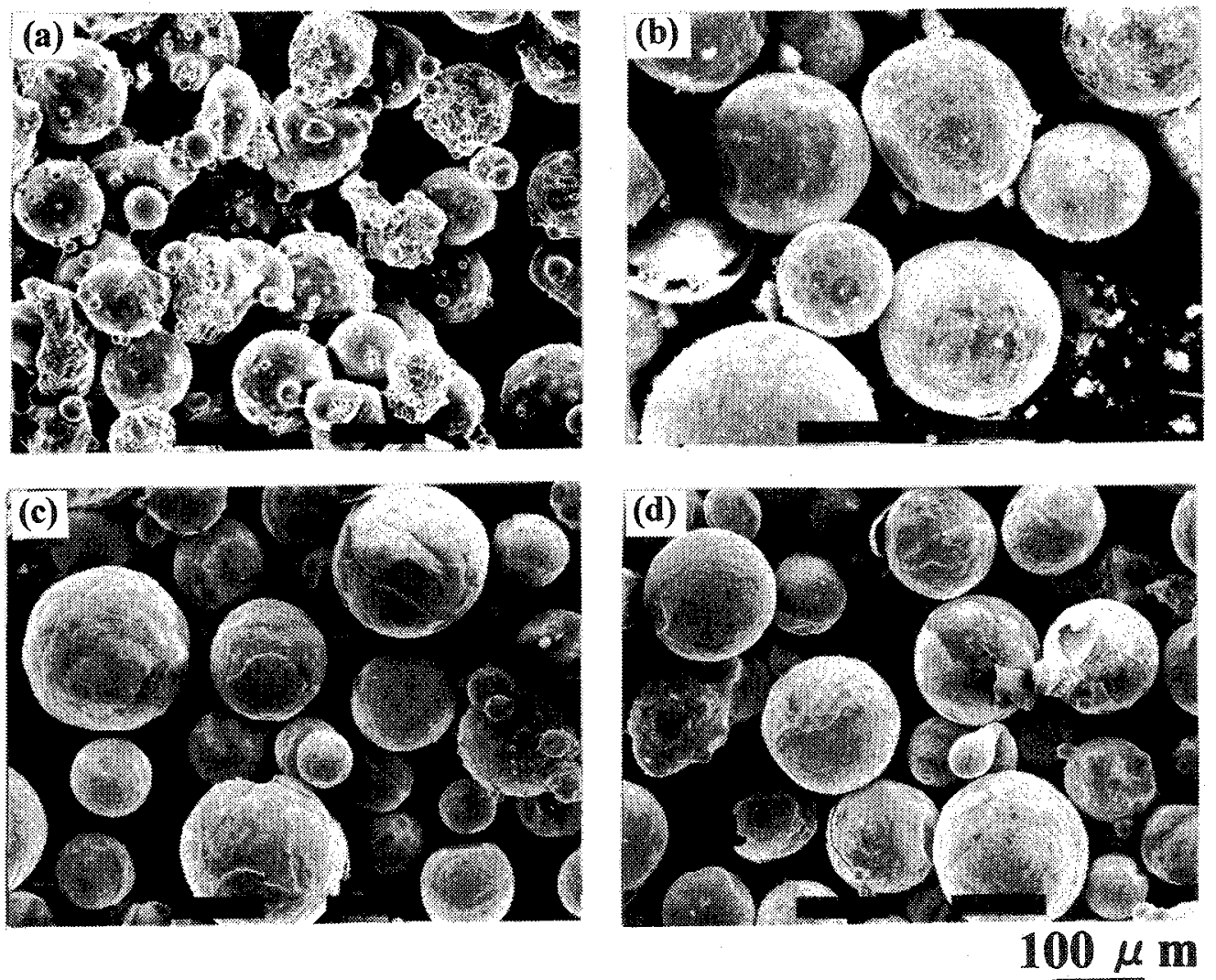

Fig. 11 Surface photographs of initial and cooled particles after heaing in plasma. Initial particles, (b) Heated particles in $60 \mathrm{~kW}$ plasma, (c) $100 \mathrm{~kW}$, (d) $150 \mathrm{~kW}$. 

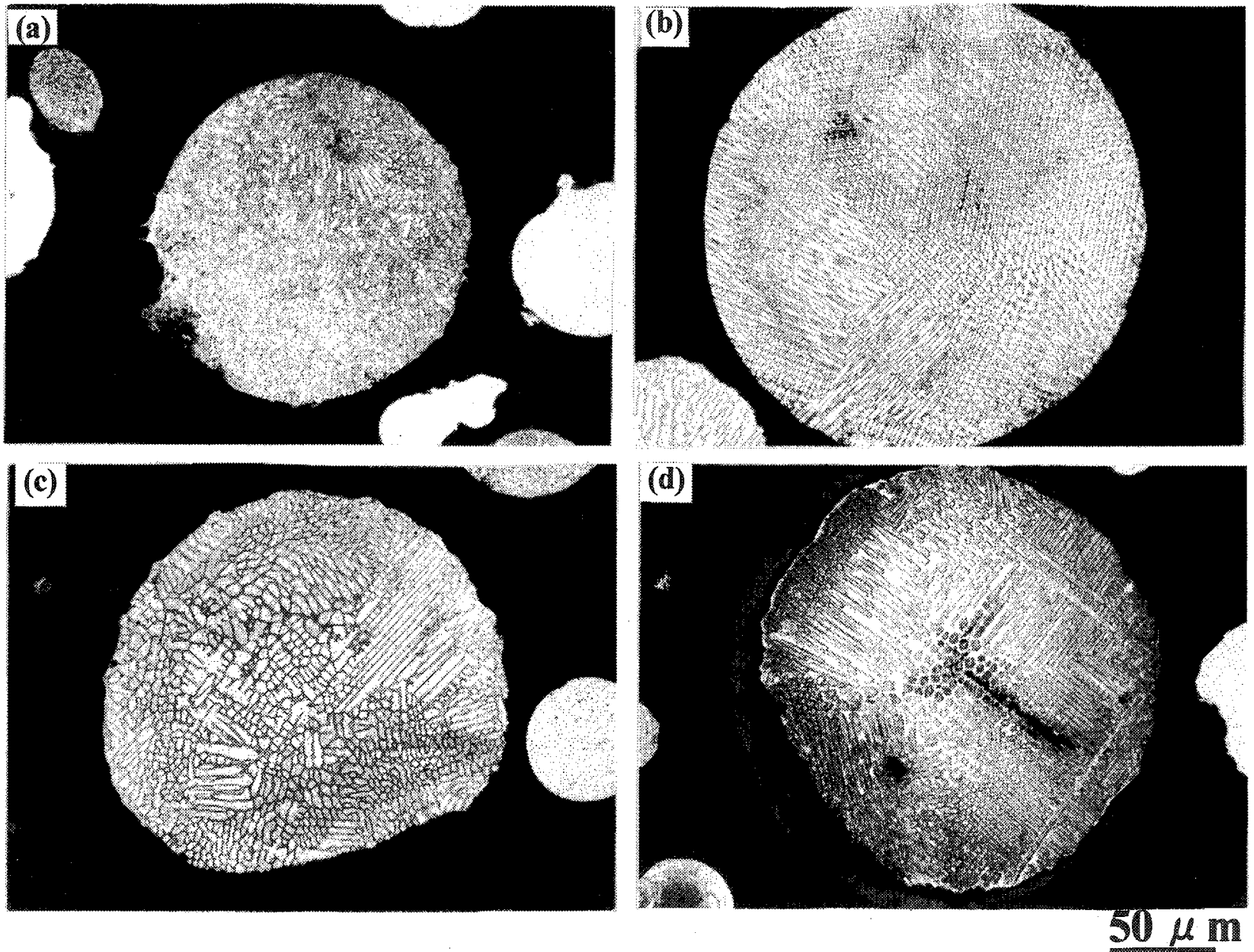

Fig. 12 Cross-sectional photographs of initial and cooled particles after heating in plasma. Initial particles, (b) Heated particles in $60 \mathrm{~kW}$ plasma, (c) $100 \mathrm{~kW}$, (d) $150 \mathrm{~kW}$.

\section{3. 溶射粒子の溶融と変形}

高周波出力を上げていった場合の溶射粒子の溶融限界を求 めるため，各出力時に粒子径を変えた粒子をプラズマに供給 し，このときの粒子の溶融状態を検討した．ただし，粒子径 を全く統一することはできないため，ここでは平均粒子径饮 よって整理する.Fig. 9 にここで用いる平均粒子径と実際 の粒子径の分布を測定した結果を示す。各分級した範囲内 で，最大粒子径と最小粒子径比が $3: 1$ に入るように分級し ている。

Fig. 10 に平均粒子径と出力の粒子の溶融状態への効果を 検討した結果を示す。このよらに粒子径に対して出力が小さ いと末溶融に，過多になると蒸発が生じる.

Fig. 11 は水槽で急冷凝固させた溶射粒子表面写真の代表 例を示している(Initial の粒子径は 27〜88 $\mu \mathrm{m}$, 溶融冷却後 の粒子径は 63〜215 $\mu \mathrm{m})$ ）、アトマイズ法で作製した原料粉 末と比較して表面が滑らか炕なっていることがわかる，各出 力でこの傾向が見られて和り，粒子の表面は全条件で溶融し たと思われる。また，本図範囲内では出力が増大するにつ

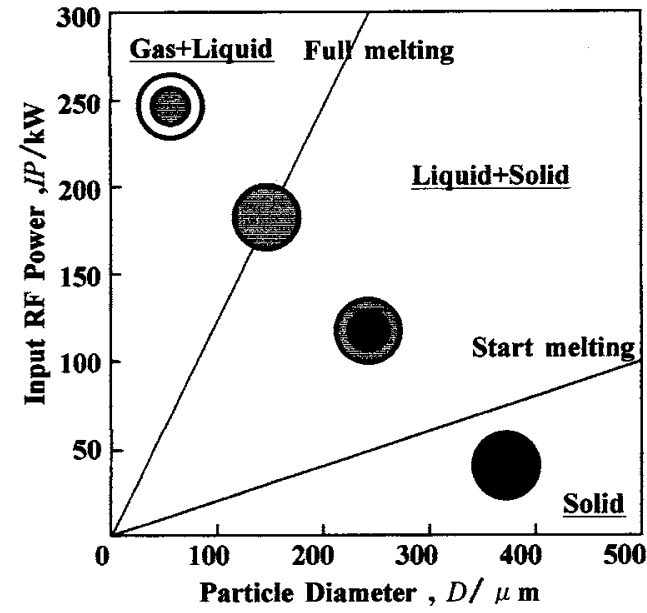

Fig. 13 Schematic diagram of the relationship between spraying condition and melting state of particles.

れ，粒子径が小さくなる傾向がある。これは出力の増加に伴 い粒子の蒸発が生じたためである。

Fig. 12 にはこの場合の粒子の断面写真を示す. $60 \mathrm{~kW}$ 時 


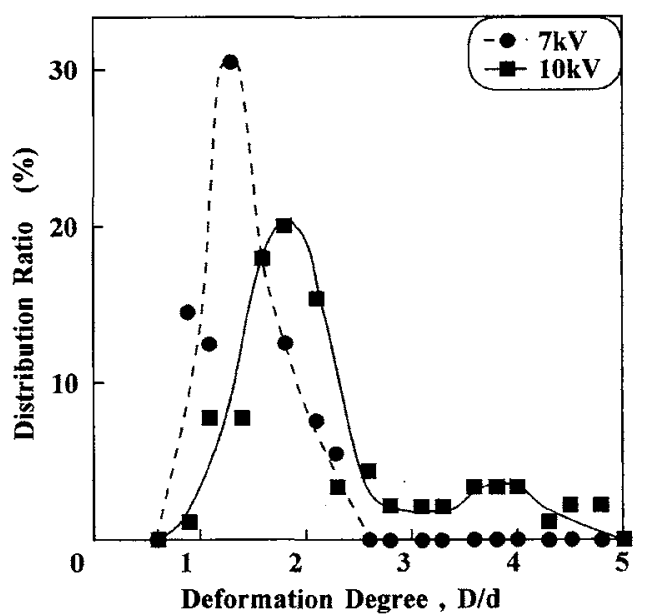

Fig. 14 The effect of the input RF power on the deformation degree.

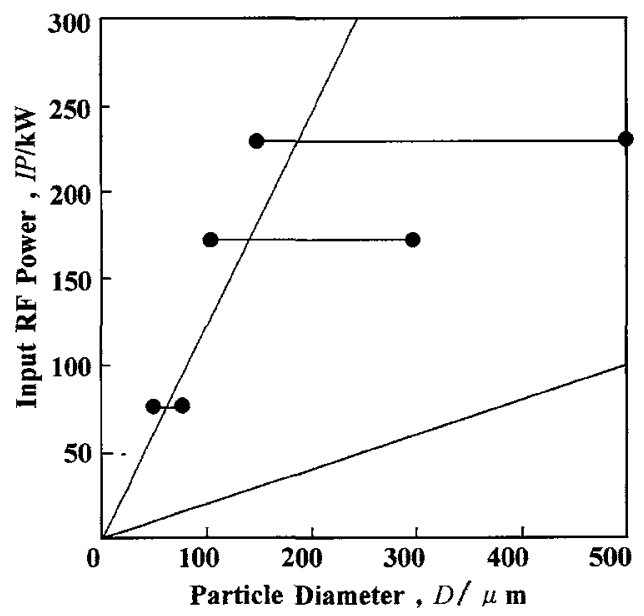

Fig. 15 Relationship between particle diameter and input RF power in the plasma spraying by the not-fully melted particles. (Experimental condition).

の組織について，粒子内部が原料粉末の内部に有する微細な

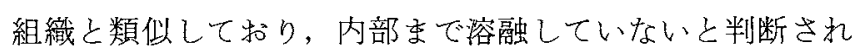
た. 一方, 出力が $100 \mathrm{~kW}$ と $150 \mathrm{~kW}$ の場合, 溶融冷却後 の粒子の組織が原料と大きく変化していることがわかる。し たがって，プラズマを通過することによって粒子が内部まで 溶融したと思われる。

このよらなプラズマ通過後の粒子の外観拉よび断面写真 や，被膜形成の有無(ない場合は未溶融，ある場合心溶融）， 叔よび溶射時の蒸発の有無により, 各粒径で各入力時の溶 融-未溶融，蒸発の有無を妾とめた概念図をFig. 13 亿示す. ここで得られた粒徍と出力による溶融・蒸発の結果から粒子 の状態を推定すると, 粒径 $(D)$ の Co 合金が溶融するか否か の溶融限界(少なくとも被膜形成飞必要な溶融量が得ら机る) の出力 $\left(P_{\mathrm{mel}}\right)$ と, 粒子が内部末で完全に溶融し蒸発が発生す る限界の出力 $\left(P_{\text {vap }}\right)$ 峘それぞれ $P_{\text {mel }}(\mathrm{kW})=D(\mu \mathrm{m}) / 5(\mathrm{~kW} /$

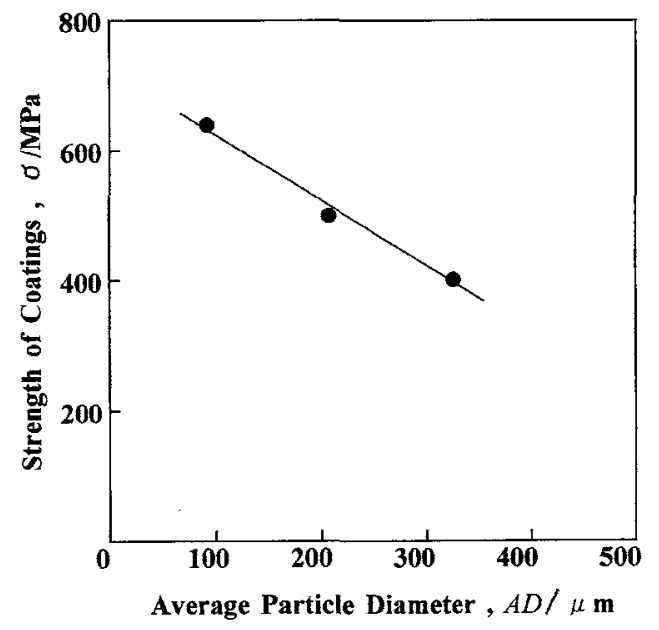

Fig. 16 The effect of strength of coating on particle diameter in the spraying by the not fully melted particles.

$\mu \mathrm{m}), P_{\text {vap }}(\mathrm{kW})=D(\mu \mathrm{m})(\mathrm{kW} / \mu \mathrm{m})$ 程度であった。この結果 と, 緻密な被膜を得るには溶射粒子の完全な溶融が必要とい うことを考慮すると ${ }^{(6)}$ ，本溶射装置(エネルギ一効率 $14 \%$, $300 \mathrm{~kW}$ のハイブリッドプラズマ溶射装置)で使用できる最 大の溶射粒子径は $300 \mu \mathrm{m}$ 程度と推定できる.

この应より，粒子径 63〜215 $\mu \mathrm{m}$ の材料については出力 $120 \mathrm{~kW}$ 程度 $(7 \mathrm{kV})$ では未溶融粒子を含み, $240 \mathrm{~kW}$ 程度 $(10 \mathrm{kV})$ では未溶融粒子を汪とんぞ含んでいないことにな る.それぞれの出力時での粒子の変形度を Fig. 14 亿示す。 横軸は变形度, 縦軸快各变形度の粒子の存在割合である. 両 出力時の変形度のピークはそれぞれ1.1と1.9にあり, 高出力 時のピーク值が約 2 倍になっていることがわかる. 変形前 の粒子温度が高い注ど粒子の変形が大きくなることから ${ }^{(6)}$, 高出力時のほうが粒子の温度が高くなっていると考兄られる。

\section{4. 溶射被膜の形成と被膜特性への粒子径の影響}

溶射粒子径の被膜特性への効果を検討するため，粒子径を 変觉て溶射を行い, 被膜強度之密着強度を測定した。特に, 本実験では Fig. 13 で求められた結果を基隹，未溶融粒子の 有無のそれぞれについての特性を測定した. Fig. 15 は未溶 融粒子を含む場合の溶射に用いた粒子径の分布之高周波出力 の関係である，分級した粒子の中で，最小径の粒子は溶融 し，最大径の粒子は完全には溶融していない。このときの被 膜強度の变化をFig. 16 亿示可。粒子径怯平均粒子径を用い ている. 粒子径の増大に伴って被膜強度が低下している。

Fig. 17 核被膜断面写真を示す. 粒子径が大きくなる任ど気 孔や界面での未接合部(黒色部：陌間または酸化物層)が大き くなっている，このことが粒子径の增大により被膜強度が低 下した原因之考光られる。

一方，未溶融粒子を含まない条件での同様な実験を行っ た。実験に用いた粒子径と高周波出力の関係を Fig. 18 に示 す．最大径の粒子でる内部季で溶融が進み，蒸発が生じてい 

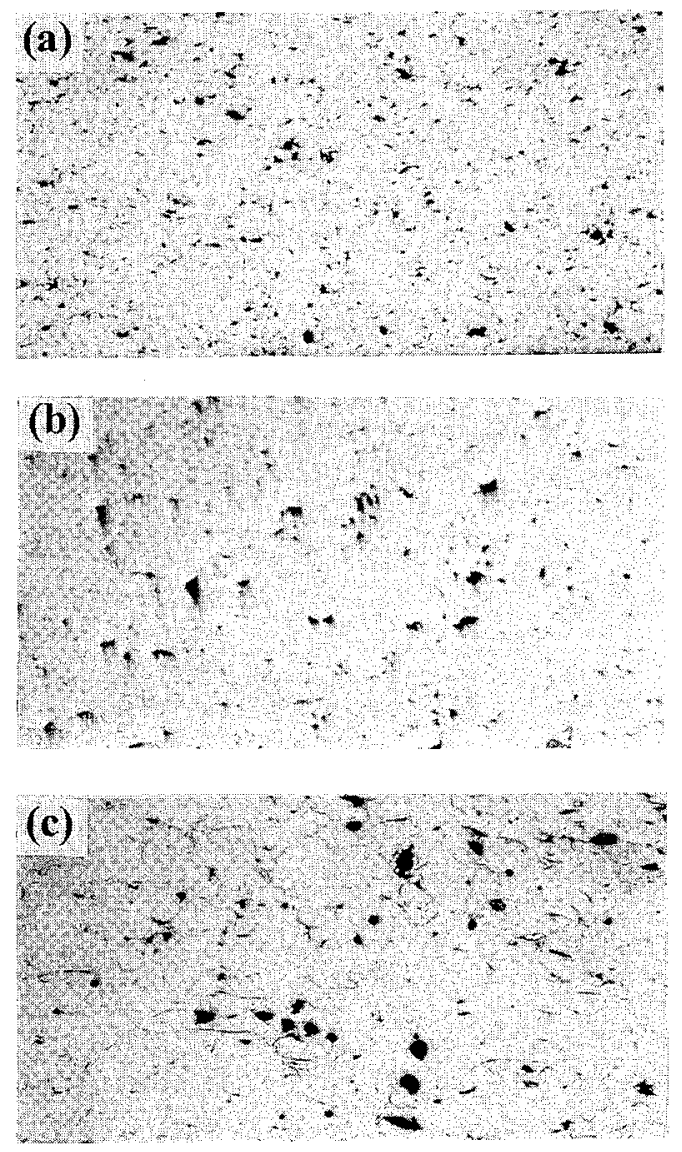

$400 \mu \mathrm{m}$

Fig. 17 Cross-sectional photographs of coatings in the spraying by not fully melted particles.

$\mathrm{RF}$ input power $=$ (a) $80 \mathrm{~kW}$, (b) $180 \mathrm{~kW}$, (c) $240 \mathrm{~kW}$.

Particle diameter $=$ (a) $55 \sim 75 \mu \mathrm{m}, \quad$ (b) $100 \sim 300 \mu \mathrm{m}, \quad$ (c) $150 \sim 300 \mu \mathrm{m}$

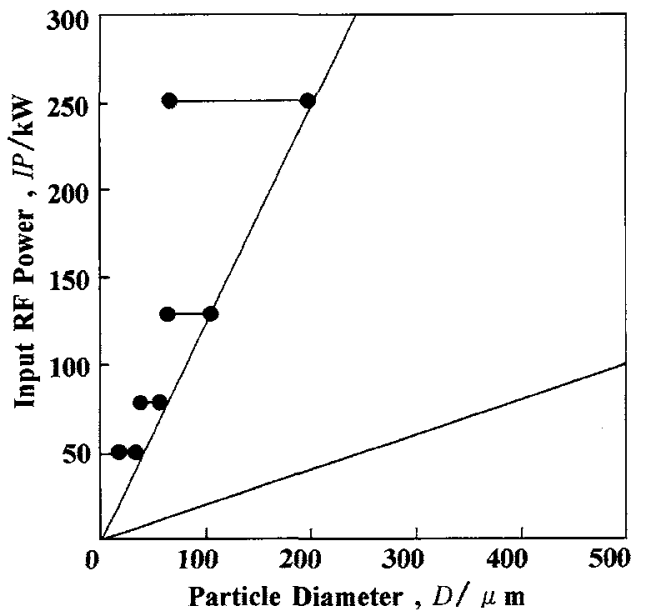

Fig. 18 Relationship between particle diameter and input RF power in the plasma spraying by the fully melted particles. (Experimental condition).

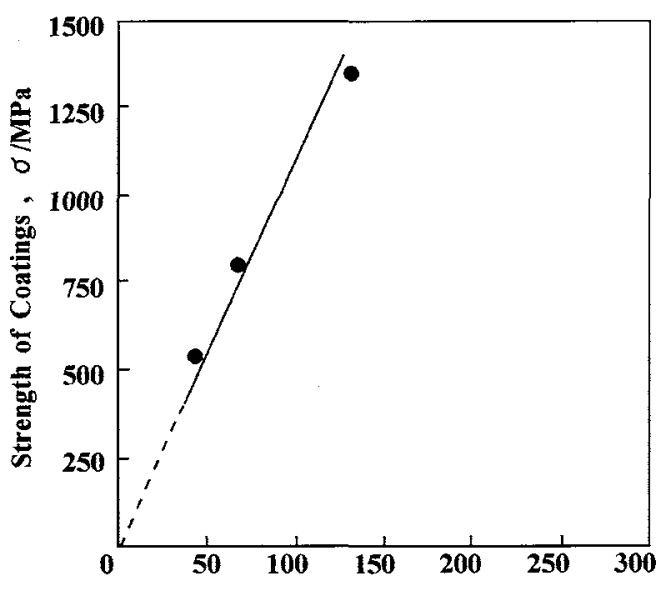

Average Particle Diameter, $A D / \mu \mathbf{m}$

Fig. 19 The effect of strength of coating on particle diameter in the spraying by the fully melted particles.

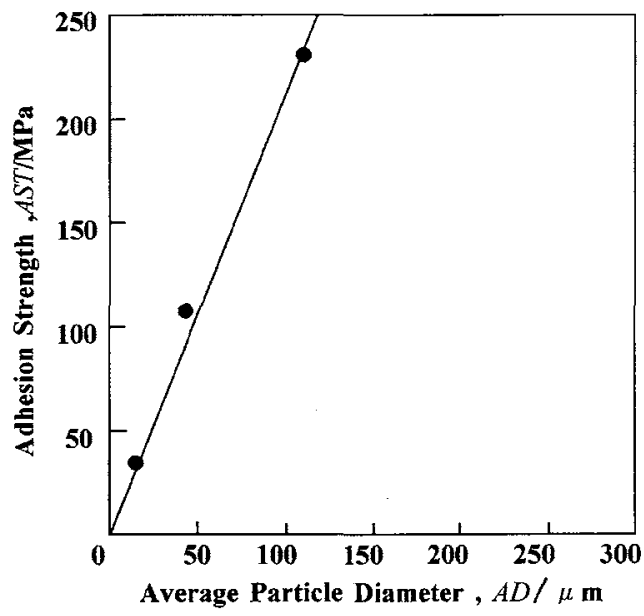

Fig. 20 The effect of adhesion strength at the interface between substrate and coating on particle diameter in the spraying by the fully melted particles.

る条件で，被膜を形成した．Fig. 19 亿粒子径と被膜強度の 関係を，Fig. 20 亿粒子径と密着強度の関係を示す，両特性 とも粒子径の增大化伴って上昇する傾向があることがわか る。るた，本装置を用いて完全溶融が可能な粒子径を用いる と，最大強度はそ机ぞれ $1350 \mathrm{MPa}, 250 \mathrm{MPa}$ であった。

この時の被膜の断面写真を Fig. 21 に示す. Fig. 17 の未 溶融粒子を含严場合と比較すると, 気孔が大幅纪低下乙てい ることがわかる。 また，粒子径の増大代伴い，被膜内部の気 孔が低減していることが大きく異なる。粒子径が大きくなる 々，粒子の熱容量が大さくなり溶射粒子間の境界層を再溶融 したり，出力増加に伴う溶射時の焼結効果が進んだことなど によると考克ている. 

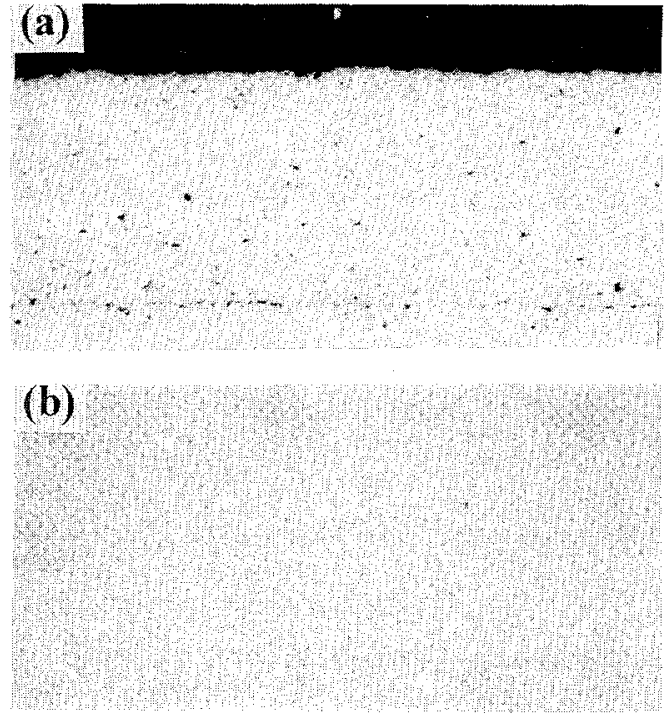

$400 \mu \mathrm{m}$

Fig. 21 Cross-sectional photographs of coatings in the spraying by the fully melted particles.

$\mathrm{RF}$ input power $=$ (a) $80 \mathrm{~kW}$, (b) $250 \mathrm{~kW}$

Particle diameter $=$ (a) $28 \sim 55 \mu \mathrm{m}$, (b) $63 \sim 215 \mu \mathrm{m}$.

\section{N. 結 論}

(1) 高周波プラズマの出力の増大に伴らプラズマ安定させ るためのガス流量の関係が明確になった。特にプラズマの熱 膨張を抑制するためには水素の効果が大さかった。

(2) エネルギー効率は出力によらず14\%程度であったけプ レート長さ $1 \mathrm{~m}$ の場合).

（3）Co 合金を溶融するための溶融限界出力，蒸発限界出 力と粒径の関係が明確になった。

（4）未溶融粒子が混在する場合, 被膜強度は粒径の増大に よって低下し，一方，存在しない場合は逆に上昇することが わかった。

\section{文献}

(1) 工藤唯輔: 溶射技術, 12, 3(1993), 75 .

（2）大割武男: 金属, 2(1981)，72

(3) E. Muelberger: Pro. 7th Int. Thermal Spray Conf., (1973), 245.

（4）竹内 順, 岡田知久, 吉田豊信, 明石和夫：日本金属学会誌, $\mathbf{5 2}(1988), 711$

(5) T. Okada, H. Hamatani and T. Yoshida: J. Am. Ceram. Soc. 72 (1989), 2111.

(6) H. Hamatani, T. Okada and T. Yoshida: Proc. 9th Int. Symp. on Plasma Chemistry, (1989), 1527.

（7）浜谷秀樹, 熊岡 尚, 八幡稔文, 吉田豊信: 日本会属学会誌 $\mathbf{5 5}(1991), 1240$.

(8) T. Yoshida: Plasma Sources Science Technology, 1(1992), 195.

（9）深沿博隆：プラズマ応用技術シンポジウム資料，末踏科学技 術協会編, (1990), 46 . 